\title{
STOCK RETURN AND TRADING VOLUME IN LQ45 INDEX
}

\author{
Clara Constantine \\ Business School, Universitas Pelita Harapan \\ Email: constantineclara@gmail.com \\ Kim Sung Suk \\ Business School, Universitas Pelita Harapan \\ Email: sungsuk.kim@uph.edu
}

\begin{abstract}
:
The relationship between return and trading volume that observed in this research is based on daily data of local LQ45 index. The Bivariate GARCH model is used to observe the relationship between return and trading volume in one-step estimation. While to investigate further relationship between these variables, the time lag correlation approach is used. To clarify the relationship, the data are divided into two big groups based on trading volume size and firm size.The result of all indexes on trading volume group shows only one way causal relationship in which return Granger-Cause trading volume but not vice versa. Meanwhile, on the firm size groups, each index shows different result. In low and medium firm size index, return causality and bidirectional trading volume, respectively. However, there is no relation found in big firm size index. All indexes for both volume size group and firm size group show a positive time lag correlation and can be called an anti-leverage effect.
\end{abstract}

Keywords: return, trading volume, Bivariate GARCH model

\begin{abstract}
Abstrak:
Penelitian ini berfokus hubungan antara return dan volume perdagangan dengan data harian perusahaan di LQ45. Model GARCH Bivariat digunakan untuk mengamati hubungan antara return dan volume perdagangan. Untuk mengetahui hubungan lebih lanjut antar variabel tersebut, digunakan pendekatan time lag correlation. Untuk verifikasi hubungan tersebut, datanya dibagi menjadi dua kelompok berdasarkan ukuran volume perdagangan dan ukuran perusahaan. Hasilnya menunjukkan bahwa kelompok volume perdagangan hanya menyebabkan Granger kausal ke volume perdangangan, tetapi sebaliknya tidak. Sementara pada kelompok ukuran perusahaan, masing-masing menunjukkan hasil yang berbeda. Pada ukuran perusahaan kecil dan menengah, return dan volume mempunyai dua arah (bilateral) Granger kausal. Namun, tidak ditemukan hubungan kausal bagi ukuran perusahaan besar. Semua kelompok ukuran volume dan kelompok ukuran perusahaan menunjukkan korelasi lag waktu positif, sehingga terdapat efek anti-leverage.
\end{abstract}

Kata kunci: return, volume perdagangan, Bivariat GARCH

\section{INTRODUCTION}

Over decades, the relationship between price changes, also known as the return, and trading volume has received considerable attention in the field of finance (Chen, 2012). Indonesia's stock market is expanding and attracts many investors in these recent years. Due to this phenomena researcher want to give more knowledge to Indonesian investor regarding Indonesia stock market since most of recent study regarding stock return and trading volume are developed in mature market rather than emerging markets, thus this research can be more reliable to emerging market especially Indonesia. By gaining or more understand regarding the stock market, investor and can be more carefully in investing or examining their strategies.

The main idea behind this research is to show the role of trading volume in pricing certain assets through the arrival of the new information (Length, 2007). Some of the evidence that was documenting the relationship between stock return and trading volume are steadily growing over time.

Stock return is used as the measurement of price changes that occurred 
over the particular period. According to capital asset pricing model (CAPM) systematic risk is associated with stock returns. That stock return can be utilized as a measurement of market risk (Ciner, 2015). Inflation and industrial production, which are classified as macroeconomic variables, are not really explaining about stock return behavior thus microeconomic variable such as trading volume; is taken into account since trading volume shows investor attractiveness towards the company.

Trading volume indicates the number of company stocks that are traded over a designated period (e.g. daily, weekly, monthly). The number of trading volume can show investors' attractiveness towards the company since higher trading volume showed a higher demand and lower trading volume showed a lower demand, which means that investors are less attracted to the company. When the numbers of shares trade are small, the market is known as illiquid, resulting in a high volatility of price. On the other hand, a large number of trading volume shows the market that is liquid. Thus, it has low price volatility (Aggarwal \& Verma, 2014). Liquidity is essential for companies' development and even their survival (Chen et al., 2015) since liquidity indicates how fast one asset can be converted into cash. It is important for the survivability because when there's an event where the company needs sources of funding in the short period they can start selling their stocks to the market as their source of financing.

The trading volume contains valuable information since it is affected by the news flows in the markets (Aggarwal \& Verma, 2014). Trading volume is also considered as an important piece of information in the market as it can cause the price move or stagnant at a certain level (Mubarik \& Javid, 2009). The Imbalance between bidders and askers, due to the information flows, is also reflected in trading volume. Therefore, trading volume can be a good proxy for information in the market and also can be used as an indicator of the quality information revealed by price, hence providing theoretical information explanation for an extensive use of volume in forecasting future stock return (Gebka \& Wohar, 2013). Trading volume also reflects the information regarding changes and agreements in investors' expectation and it also contains valuable information on the market ( Length, 2007).

Price changes or return has been taken as a primary indicator to measure market risk, while trading volume quantifies market liquidity (Chen et al., 2015).

The price-volume relationship can be a critical input for various market players since investors are always seeking positive rate of return and demanding higher return with lower risk (Aggarwal \& Verma, 2014). To achieve these objectives, investors are evaluating the market carefully and continuously. As a proxy for information, trading volume can be a tool for investors to reevaluate their valuation regarding the stock market (Mulherin, Foundation, \& Long, 1993). According to Karpoff, besides enhancing the knowledge on the financial market, the relationship between return and volume increase the knowledge on the financial market structure, and it also provides information to discriminate various competing theoretical models (Chen, 2012). The result from Campbell et al. shows the relationship between return and trading volume can help to solve the identification problem from different testing models (Chen, 2012).

The relationship between return and trading volume has been documented in several kinds of literature by different authors. Some documentation mentions about folklore, where it is believed that trading volume is positively associated with the stock return. According to Karpoff (1987), to move price, it takes volume, as significant price fluctuation is related to strong buying and selling pressure that will make the price of stocks significantly move up or down respectively.

Campbell et al. (1993); Wang (1994); and Llorente et al. (2002) have argued that volume and the stock price has a complex relationship rather than linearly affecting one another. Thus, in conclusion, if trading is motivated by private information such as liquidity or hedging, then the prices on days of heavy trading days must show 
continuations (reversals) on subsequent days, resulting in positive (negative) stock return autocorrelations.

According to Al-Jafari (2011), the economic variable is not only affecting the stock price but is also affected by the stock price itself. Through this statement, researcher wants to see how one element responds to another both how the price (return) affected by trading volume and how the trading volume is affected by price (return).

\section{RELATED LITERATURE AND HYPOTHESIS DEVELOPMENT}

\section{Trading Volume to Return}

Return can be used as an indicator of market risk, which can be observed from CAPM model formula. The formula also shows that an increase in the systematic risk leads to the increase in return. This makes the investors demand more in exchange for the risk. Trading volume quantifies market liquidity, which is important for the company for both the development and the survival of the company (Chen et al., 2015).

Therefore, various researches regarding to the relationship between trading volume and return have increased recently, especially about the influence of price on trading volume. It is believed that return and volume has a positive correlation. When the price falls, trading activities in the market will also decrease resulting in small trading volume and vice versa. The decreasing activities in the market will lead to a low trading volume and vice versa.

The arrival of new information is reflected in trading volume; hence it can be a good approximation in correcting the price disagreement in the market thus contains valuable information regarding future price movement (Sapna \& Dani, 2014). According to Llorente et al. (2002), to identify the periods in which allocation or informational shocks occur, one could use the intensive trading volume and hence it might provide valuable information about future price dynamics.

Information is one of the factors that affect trading volume besides liquidity, volume breakout, and previous return, which correlates the most to the fundamental valuation of the security. The other important factor is the previous return which affects the investor decisions.

In 2007, another research found out that large market-wide returns strongly influence wide trading volume which happens in the whole world (Assan \& Thomas, 2013) While in 2008, it was found that return Granger-Cause trading volume in Chilean stock market (Assan \& Thomas, 2013). Lastly, in 2011 a research that was done by Abdelgader, the research concluded that return leads volume in five out of seven markets (Yadav, Aggarwal, \& Khurana, 2015).

However, there are some researches that found out the contradictory results about relationship between return and trading volume. In the period between 1995 to 2000, multiple researches were done by the researchers concluded that the market researches in Southeast Asia, America, Central and Eastern Europe, Korea, and China were inconclusive to confirm the relationship between return and volume (Pisedtasalasai \& Gunasekarage, 2007).

\section{Return to Trading Volume}

Market breaks on 1987 and 1989, leads to progression of price and trading volume relation, where high price volatility couple with large trading volumes (Ghysels, Gouriéroux, \& Jasiak, 2000). Many researches regarding the relationship between stock price or return and trading volume have been done by various researchers. Various type of securities such as futures, indices, and individual stock with different time length data (yearly, monthly, weekly, daily, and hourly) have been studied to see the relationship between these variables.

When there is a transaction, and the price doesn't change, there must be a price agreement between seller and buyer that differs from previous quotes to have a price change. In the liquid market, the large number of buyer and seller indicates a strong buying and selling pressure which lead the large price fluctuations to significantly up or slump (Queirós, 2016). Bohl and Henke (2003) mention that appropriate proxy of 
information such as trading volume can be lowering country's volatility.

The mixture of distribution model by Pisedtasalasai \& Gunasekarage (2008), propose a causal relationship between trading volume and return. Trading volume was used to measure different traders' perception; when new information reaches the market, traders are more likely to reexamine their price level. Arrival of "good" information in the market results in price increase whereas arrival of "bad" information in the market result in price decreases. As the degree of disagreement among market participants gets wider, the level of trading volume increase or can be said the level of trading activity is above average. Contradict with the previous result, trading volume does not causal return.

Chen (2012) believed that trading volume is positively associated with stock returns. Documented literature by Karpoff (1987) also shows a positive correlation between volatility and trading volume, "it takes volume to make price move".

Another result by Mckenzie and Faff (2003) found volume has a positive correlation with the return but negatively with volatility level, meaning individual stocks highly dependent on trading volume. Gebka \& Wohar(2013) only two out of ten Asian markets show that volume cause return. A research in the Pacific Basin Countries showed strong non-linear causality using quantile regression. Quantile regression is used in the research because the causality cannot be found using ordinary least square. The investigation of Tokyo Stock Exchange by Bremer and Hiraki(1999), show that trading volume is useful for predicting following stock return. Previous day trading volume is used as a tool in predicting future stock return. The previous trading volume is known as lagged trading volume. Besides that, the lagged trading volume is important information in price movement (Yadav et al., 2015). From the result of Ciner's and Cetin's (2015) investigation, shows that there is a significant dependency between trading volume and return based on the evidence from the investigation of the time variation in systematic risk, return, and trading volume by using quantile regression. Quantile regression is utilized in the investigation since the ordinary least square regression cannot capture the phenomena.

In contradict some researches failed to find the significant relationship between return and volume. The early research by Granger \& Morgenstern (1963) fails to find the correlation between price index and volume level. The result from Lee and Rui(2000) report that on next day, Chinese index return is not forecasted by volume. Darrat et al. (2003) examine that there is no significant contemporaneous correlation between volume and return volatility. Research by Chen et al. (2001) found no causal between price and volume in 5 countries which are France, Italy, Japan, UK, and US.

\section{Two Ways Causal Relationship of Return and Trading Volume}

Based on the available set of information about a company, investor expectations regarding future performance of the company is reflected in stock return. Investors adapt their expectation based on arrival information in the market. Besides that, information flow in the market is the primary variable that affects the movement of price and trading volume (Otavio, Medeiros, Ferdinandus, \& Doornik, 2006).

Understanding the causal relationship between return and trading volume can help investors to frame different market strategies for gaining more profit and avoiding losses, since the expected return in stock markets are varied over time. Deeper understanding the regarding relationship between return and trading volume can help investors to understand the microstructure of stock market thus help investors with better strategies (Yadav et al., 2015).

One of the models developed to estimate the relationship between these two variables is the sequential information arrival model. In this model, information is considered not disperse to all market participant simultaneously. Meaning the flow of information is asymmetric. In this model, several equilibriums are achieved before the final equilibrium is reached. Because flow of information in the market is 
sequential, it can be said that lagged volume may contain information that may be useful in predicting current return and otherwise lagged return may contain information in predicting current trading volume (Pisedtasalasai \& Gunasekarage, 2007).

Some number of researches have been conducted to investigate the relationship between return and trading volume, especially how each variable affect each other and come out with several results. It was found in 1987 that the relationship between returns and volume is two ways causal; this is also confirmed by a research in 1995 where 3 out of 4 countries have bidirectional causality. The relationship between returns and trading volume is also fortified by a recent research in 2008 which shows that volume causes return and return causes volume implying that this is bidirectional Granger-Causality. Whereas in the Indian stock market shows strong causality between stock return and trading volume. In the Indian stock market, $66 \%$ of the stocks indicates that return causes volume, $3.3 \%$ shows that volume causes return, $3.7 \%$ shows bidirectional causality between these variables, meanwhile around $27 \%$ of the stocks shows there is no causality at all (Yadav et al., 2015). Both researches in 1994 and 1998 show the bidirectional lead-lag relation between return and trading volume (Assan \& Thomas, 2013).

Another result conducted in emerging market by Moosa and Al-loughani in 1995 indicates that the causal relationship between those variable only exist between volume to price but not from price to volume (Assan \& Thomas, 2013).

In 2007 a research found a bidirectional relationship where a return has linear explanatory power over trading volume, meanwhile volume has non-linear explanatory over return (Assan \& Thomas, 2013). Chen conducted a research regarding return, trading volume, and volatility relations in nine major markets that showed eight of nine markets show return causes volume meanwhile only four out of nine show volume causes return.

\section{Leverage and Anti-Leverage Effect}

To understand further relationship regarding price return and trading volume, the leverage and anti-leverage effect are taken into account to see how each factor affect other in the future. There are three types of correlation between return and trading volume: leverage effect, antileverage effect, and no effect or each variable is independent one to another (Chen et al., 2015).

Trading volume is reacting to the price change. When the price rises, people are more likely to do trading to make money or gain some profit which leads to high trading volume, on the other hand when the price goes down, the trading volume could be shrink which leads to low trading volume. When the correlation between return and trading volume is feeble with the coefficient nearly zero, this can be said that the trading volume almost independent from the return. It means there is almost no effect on return and trading volume.

When the correlations even transit to negative values, this indicates an adverse movement between return and trading volume (Shen \& Zheng, 2012). When the price goes up, this induces a small trading volume, while a large trading volume is induced when the price goes down. The result of more than ten days negative correlations between return and volume named as 'leverage effect', meanwhile more than ten days positive correlations known as 'anti-leverage effect' of the return-volume correlations.

\section{Hypotheses Formulation}

The trading volume contains information that is reflected in the stock price that cannot be obtained from the stock price alone align with this statement trading volume widespread is also used to predict price changes using technical analysis. Trading volume also act as a signal to the market to predict stock return autocorrelation (Ciner, 2015). Trading volume can be a good proxy for price adjustment in the market (Pisedtasalasai \& Gunasekarage, 2007). 
When there is price disagreement in the market, trading volume can be used to reexamine the price level until meeting the equilibrium level, thus it can be said that trading volume has explanatory power in examining the stock price level in the market. Examining the relationship of trading volume to return can help investor reevaluate their strategies regarding stock market thus can maximize their return on their stock or portfolios. Bremmer and Hiraki (1999), show that trading volume is useful for predicting following stock return. Empirical evidences of influence of trading volume to return are supported by Assan \& Thomas(2013) and Yadav, Aggarwal, \& Khurana, (2015). Based on the explanation above the hypothesis one is developed where trading volume has influence to stock return in the market.

\section{H1: Trading volume has influence to} stock return

Trading volume was used to measure different traders' perception; when new information reaches the market, traders are more likely to reexamine their price level. Arrival of "good" information in the market results in price increase whereas arrival of "bad" information in the market result in price decreases (Ane \& Urecherangau, 2008). The large number volume transections indicates a strong buying and selling pressure which lead the large price fluctuations to significantly up or slump (Queirós, 2016)

Mckenzie and Faff (2003) found volume has a positive correlation with the return. Empirical results from Yadav et al.(2015) and Ciner's and Cetin's (2015) also showed that effects of stock return to trading volume. Based on the explanation above the hypothesis two is developed where stock return has influence to trading volume in the market

H2: Stock return has influence to trading volume
The anti-leverage effect happens when more than ten days the correlations between return and trading volume show positive values (Shen \& Zheng, 2012; Chen et al., 2015). This indicates synchronous movement between return and trading volume. It is believed that stock return and trading volume has positive correlation, when the price goes up this will induce a high trading volume, while a low trading volume is induced when the price goes down.

The mixture of distribution approaches introduced by Clark provided the contemporaneous correlation between stock return volatility and trading volume. It shows that variances for both price changes and trading volume are driven by same inherent variable measuring the number of pricerelevant information arriving on the market. Arrival of good news arrived in the market, resulting price increase in the market, meanwhile arrival of bad news in the market resulting price decrease in the market. The events are accompanied by increase of trading volume activity in the market thus leads to new equilibrium in the market. Therefore trading volume and stock return (volatility) will thus display a positive correlation due to their common dependency on the latent information flow process Chet et al., 2015). Based on the explanation above the hypothesis three is developed where trading and stock return has positive correlation or anti-leverage effect.

\section{H3: Return and trading volume have anti-leverage effect}

\section{DATA AND EMPIRICAL MODEL}

\section{Data}

Data that are used in this research are all company ever listed in the LQ45 index. The LQ45 index is a stock market index for Indonesian Stock Exchange (Jakarta Stock Exchange). The LQ45 
index consists of 45 companies listed on Indonesia Stock Exchange which are examined semi-annually that achieve certain criteria. The criteria are:

1. Companies with highest market capitalization in the last 12 months

2. Companies with highest transaction value in the last 12 months

3. Has been listed for at least 3 months in Indonesia Stock Exchange

4. Good financial conditions, with prospects of growth and high frequency and transaction value

Therefore LQ45 can be classified as group of companies with high market capitalization and high transaction value and frequency or known as liquid. The
LQ45 companies list used as the data since it consists of companies that have high-frequency trading volume (liquid). The research are limited using the LQ45 index because researcher aimed to capture the phenomena of stock return and trading volume using the high frequency companies and eliminated the outliers data such as zero volume size companies in the market.

All the data are observed for ten years period; the data period cover years from February 2006 January 2016 and these data are daily observation both for each company. Longer data are used so the result expected to have low errors or standard deviation and can capture the phenomenon happen during the period. There are total 74 companies and the LQ45 index used in this research.

Table 1. Companies List

\begin{tabular}{lll}
\hline No. & Data & Total \\
\hline 1 & $\begin{array}{l}\text { Companies listed in the LQ45 index from February 2006 to } \\
\text { January 2016 }\end{array}$ & 115 \\
2 & $\begin{array}{l}\text { Companies that are no qualified in the research due to missing } \\
\text { data and lack of observation time period }\end{array}$ & 41 \\
\hline & Total Companies & 74 \\
\hline
\end{tabular}

Source: based on IDX listed firms

From Table 1, there are 41 companies removed from the observation because some of the companies are changed from public company to private company and others do not have complete ten years observation data. Since all the data needed for this research is historical data, so the data collected is called secondary data. The data was taken from various resources to support data this research.

The data required in this research is determined below:

1. Companies ever listed in LQ45 index daily adjusted closing stock price
2. Companies ever listed in LQ45 index daily trading volume

Some outliers' data and incomplete data are removed from this research, to minimize the error of the result.

Bivariate GARCH model is used in this research to investigate the causal relationship between return and trading volume and between return volatility with trading volume. Both of the calculation can be measured using onestep estimation procedure so it would be more efficient (Chuang, Liu, \& Susmel, 2012) 


\section{Conditional Mean Equations}

Conditional mean equations of bivariate model are used to investigate the causal relationship between stock return and trading volume and also between trading volume and lagged return volatility.

The following equations are the model used in this research:

$$
\begin{aligned}
& R_{t}=\alpha_{R, 0}+\sum_{a=1}^{A} \beta_{R, a} R_{t-a}+\sum_{b=1}^{B} \Upsilon_{R, b} V_{t-b}+\varepsilon_{R, t} \\
& V_{t}=\alpha_{V, 0}+\sum_{c=1}^{C} \beta_{V, c} R_{t-c}+\sum_{d=1}^{D} \Upsilon_{V, d} V_{t-d}+\sum_{e=1}^{E} \delta_{V, e} \varepsilon_{R, t-e}^{2}+\varepsilon_{V, t}
\end{aligned}
$$

$R_{t}$ represents the log stock return at time $\mathrm{t}$ and $V_{t}$ represents the $\log$ trading volume as percentage of number of share at time t. Lag length for both equation (1) and equation (2) are differently chosen according to the Autoregressive Distribution Lag Model (ARDL). For example the lag length for return for equation (1) and lag return in equation (2) will be different.

Lagged square errors from the return equation are added up in equation (2) as a measurement of return volatility. Return volatility is included in volume equation to investigate whether lagged return volatility caused trading volume or not. The specification for both equation (1) and equation (2) are not following the standard form or VAR representation since those have different independent variable, but still following the rationale the causality as the same as Granger-Causality test.

The coefficients $Y_{R, b}$ measure the causal relationship between current stock return and lagged trading volume, while $\Upsilon_{V, d}$ measure the causal relationship between lagged return and trading volume and coefficients $\delta_{V, e}$ measure the causal relationship between lagged return volatility and trading volume.

The null hypothesis in equation (1), where the coefficient of lag trading volume to return as denoted by $\Upsilon_{R, b}$ equal to zero, shows that trading volume doesn't GrangerCause stock return. Rejection of the null hypothesis indicates a causality running from trading volume to stock returns. The test is run analogously in equation (2) for both coefficient lag return to trading volume $\Upsilon_{V, d}$ and coefficient lag return volatility to trading volume $\varphi_{V, e}$ to see the causal relationship between current trading volume and lagged return and also between current trading volume and lagged return volatility.

The sign or net effect of Granger Causality also can be tested, whether the sum of the coefficient of $Y_{V, d}$ is bigger than zero.

\section{Conditional Variance-Covariance Model}

Constant correlation bivariate

GARCH model used to model the dynamics of the second moments of stock returns and trading volume and the causal relations between current return volatility and lagged trading volume. Conditional variance used is the GARCH specification. This specification allows the prior positive and negative volatility shock to have a different asymmetric impact on the conditional variance.

The GARCH specification model for return and trading volume are shown below:
$\sigma_{R, t}^{2}=\omega_{R}+\sum_{n=1}^{N} \delta_{n, p} \sigma_{R, t-n}^{2}+\sum_{0=1}^{O} K_{R, o}\left(\varepsilon_{R, t-o}\right)^{2}+\lambda_{R} S_{R, t-1}^{-}\left(\varepsilon_{R, t-1}\right)^{2}$
$\sigma_{V, t}^{2}=\omega_{V}+\sum_{p=1}^{P} \delta_{V, p} \sigma_{V, t-p}^{2}+\sum_{q=1}^{Q} K_{V, q}\left(\varepsilon_{V, t-q}\right)^{2}+\lambda_{v} S_{v, t-1}^{-}\left(\varepsilon_{v, t-1}\right)^{2}$

The conditional variance of stock returns and trading volume at time $\mathrm{t}$ is denoted with $\sigma_{R, t}^{2}$ and $\sigma_{V, t}^{2}$ respectively. The dummy variable is shown in equation (3) and equation (4) which denoted as $S_{R, t-1}^{-}$and $S_{v, t-1}^{-}$, when the value of the coefficient $\varepsilon_{R, t-1}$ less than zero and $\varepsilon_{v, t-1}$ less than zero the dummy variable will take on a value of one and zero otherwise. The specifications for equation (3) and (4) have different ARCH and GARCH effect on stock return and trading volume.

Negative news is captured by the coefficients $\lambda_{R}$ and $\lambda_{v}$ in the equation (3). If 
the coefficient shows the value bigger than zero, it indicates a negative return shock has a bigger impact on its conditional variance rather than a positive return on an equal

$$
\sigma_{R V, t}=\sigma_{V R, t}=\rho_{R V} \sigma_{R, t} \sigma_{V, t}
$$

\section{Leverage and Anti-Leverage Effect}

To know how the price changes drive the future trading volume and vice versa the time-lag return-volume correlation magnitude. The constant correlation GARCH model imposed following restriction on the variance between stock returns and trading volume.

$\mathrm{L}$ are used to measure this relationship whether have positive or negative time lag correlation (Chen et al., 2015):

$$
L(\tau)=\left\{\frac{\left\{\left(r_{t^{\prime}}-\{r\}_{t^{\prime}}\right)\left(v_{t^{\prime}+\tau}-\{v\}_{t^{\prime}+\tau}\right)\right\}_{t^{\prime}}}{\sigma_{r} \sigma_{v}}\right\}_{t^{\prime \prime}}
$$

Where $r$ is denoted as return and $v$ is denoted as trading volume. Where $t^{\prime \prime}=1, \ldots$ , T $-\mathrm{W}$ and $\mathrm{t}^{\prime}=\mathrm{t}^{\prime}, \ldots, \mathrm{t}{ }^{\prime \prime}+\mathrm{W}-1$, with $\mathrm{T}$ is total investigated time period and $\mathrm{W}$ to be a moving window of 260 days (about one year working days), $\tau$ is the time lag, $\{\ldots\}$ represent the average value over the correspondent time, where

$$
\sigma_{r}=\sqrt{\frac{1}{W} \sum_{t^{\prime}=1}^{W}\left(r_{t^{\prime}}-(r)_{t^{\prime}}\right)^{2}} \sigma_{q}=\sqrt{\frac{1}{W} \sum_{t^{\prime}=1}^{W}\left(v_{t^{\prime}+\tau}-(v)_{t^{\prime}+\tau}\right)^{2}}
$$

We estimate return as follows, $R_{t}=\log \frac{P_{t}}{P_{t-1}}$, where Pt is the stock price at the time of the $t$. On the other hand we estimate trading volume as follows $\mathrm{V}_{\mathrm{t}}=\log \frac{\mathrm{TV}_{\mathrm{t}}}{\text { Numberofs haresoutsanding }}$, where $\mathrm{TVt}$ is the trading volume of specific date.

The consistency of bivariate GARCH model and the data used are tested through three tests, which are Unit Root test, Lagrange Multiplier ARCH test, and White Noise test.

\section{EMPIRICAL RESULTS}

\section{Descriptive Statistics}

There are 74 companies used in this research. The companies are classified into volume size group which is divided into three different indexes. The proportions of each indexes used in this research are based on Fama-French (1993). The volume size group is divided into three indexes: high, medium, and low which the proportions are $30 \%$, $40 \%$, and $30 \%$ respectively. All the indexes are estimated using a simple average of the listed companies in the index.

Table 2. Descriptive Statistic Based on Volume Size

\begin{tabular}{lcccccc}
\hline A. Based on Volume Size & \multicolumn{7}{c}{} & & & \\
\hline & Mean & Standard Deviation & Maximum & Minimum & Skewness & Kurtosis \\
\cline { 2 - 7 } Return High & 0.0001 & 0.0069 & 0.1310 & -0.0545 & 4.0424 & 90.7172 \\
Return Medium & 0.0004 & 0.0090 & 0.3350 & -0.0419 & 20.4353 & 745.4607 \\
Return Low & 0.0004 & 0.0078 & 0.2954 & -0.0226 & 23.7552 & 851.1925 \\
Volume High & -3.5851 & 1.2636 & -2.1831 & -9.9320 & -3.0075 & 12.9804 \\
Volume Medium & -3.5823 & 1.2698 & -2.6253 & -10.0670 & -3.8147 & 17.4244 \\
Volume Low & -4.5693 & 0.9251 & -2.8656 & -9.8588 & -3.3237 & 17.1105 \\
\hline
\end{tabular}

Source: Calculated based on the previous mentioned data 
The result shows that return for all indexes has a positive mean and skewness. These indicate that the distribution is skewed to the right since it has a longer right tail than it left tail. The kurtosis of trading volume is smaller than the kurtosis from return, high number of kurtosis indicated the distribution of return is fat-tailed compare to trading volume.

\section{Stock return and trading volume relationship}

Table 3. Lag Length Based on Volume Size

\begin{tabular}{llllll}
\hline & \multicolumn{5}{c}{ Lag Length } \\
\cline { 2 - 6 } High Volume & A & B & C & D & E \\
\cline { 2 - 6 } Medium Volume & 1 & 5 & 1 & 7 & 1 \\
Low Volume & 1 & 1 & 1 & 4 & 2 \\
\hline Source: & 1 & 1 & 7 & 1 \\
\hline
\end{tabular}

Source: calculated based on the previous mentioned data

Table 4. Granger Causality Result for Volume Size

\begin{tabular}{lcc}
\hline Volume to Return & P-Value & Result \\
\hline High Volume & 0.0895 & Insignificant \\
Medium Volume & 0.2669 & Insignificant \\
Low Volume & 0.3521 & Insignificant \\
Return to Volume & & \\
\hline High Volume & 0.0000 & Significant \\
Medium Volume & 0.0000 & Significant \\
Low Volume & 0.0074 & Significant \\
& & \\
Return Volatility to Volume & & \\
\hline High Volume & 0.3480 & Insignificat \\
Medium Volume & 0.5998 & Insignificat \\
Low Volume & 0.0033 & Significant \\
\hline Source: Calculated based
\end{tabular}

Source: Calculated based on previous mentioned data

Table 4 shows the estimation for the bivariate model for three different indexes based on trading volume size. The significant result shows a causal relationship between two variables, meanwhile insignificant result shows that there is no causal relationship between two variables.

Using $95 \%$ confidence interval, the Wald test is used to test the null hypothesis. The null hypothesis in this research is "there is no Granger-Causality between two variables". Meanwhile the alternative shows there is Granger-Causality between the variables. To determine whether null hypothesis is accepted or rejected the PValue is taken into account. When the PValue is bigger than 0.05 , the null hypothesis is failed to reject, meaning that there is no correlation between the variables, each variable doesn't Granger-Cause other variable. On the other hand, when the PValue is smaller than 0.05 , the null hypothesis is rejected, and the alternative hypothesis is accepted indicating that there is a causal relationship between two variables.

In the high volume size index, the null hypothesis for volume to return can not be rejected, this indicates volume does not Granger-Cause return. Meanwhile return to volume result shows an opposing result. Zero P-value indicates that the null hypothesis is rejected, thus shows a causal relationship between return to trading volume. Meanwhile there is no evidence shows a relation of return volatility to trading volume. 
In the medium volume size index the similar result is found. The results only show one-way causal relationship where return Granger-Cause trading volume but not vice versa. There is also no evidence regarding return volatility to trading volume in this index.

In the low volume size index there is only one way causal relationship from return to trading volume. There are also some evidences that return volatility Granger-Cause trading volume in this index.

It can be concluded that all index in volume size groups only shows one way causal relationship where return GrangerCause trading volume but not vice versa. It is only found that return volatility Granger-
Cause trading volume in low volume index but there is no evidence from high and medium volume indexes.

In the previous research, it is also shown that in the developing markets, there is only one-way causal relationship from return to trading volume (Chuang et al., 2012). This is also confirmed in this research for which the high volume category shows a strong affection of the return to the trading volume. It is suspected that the one-way causality between the return and the volume is caused by the behavior of the investors, where in Indonesia, people tend to invest more in the company which has more return value without really focusing on the volume size.

\section{Leverage and Anti-Leverage Effects}

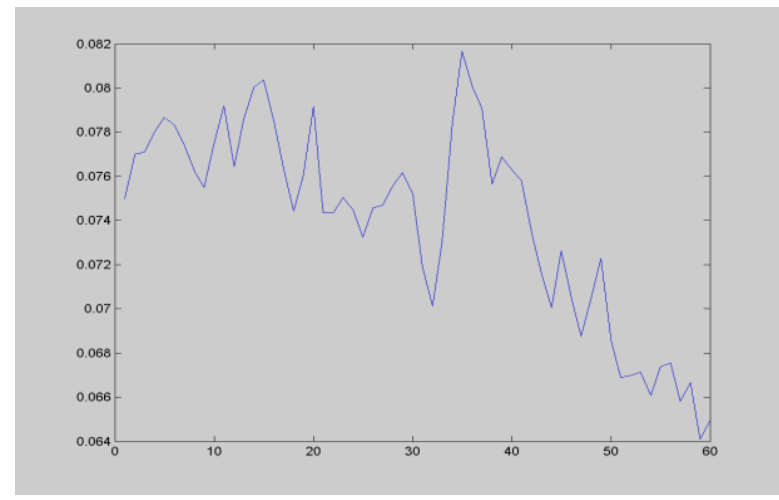

Source: calculated based on previous mentioned data

Figure 1.High Volume Size

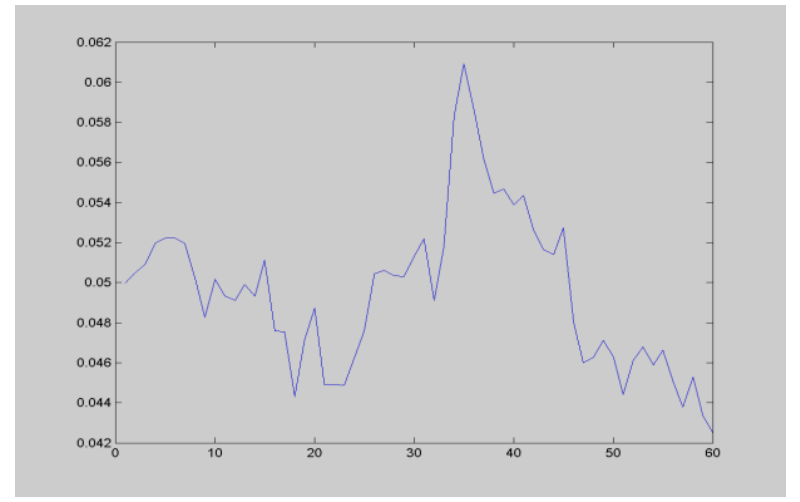

Source: calculated based on previous mentioned data

Figure 2. Medium Volume Size

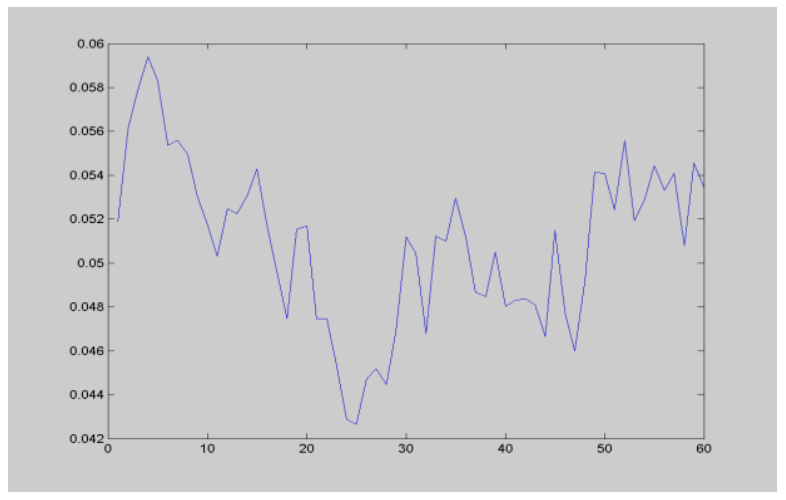

Source: calculated based on previous mentioned data

Figure 3. Low Volume Size 
All the three indexes show a similar result where return and trading volume has positive time lag correlation, shown by the graph above. The results shows that return and trading volume has positive time lag correlation more than ten days time lag thus can be said that return and trading volume has an anti-leverage effect.

\section{CONCLUSION}

All data was analyzed and showed different relations in comparison to the previous researches. Some of the previous researches also used bivariate GARCH Model for the analysis and yet they still show different relation in comparison to the results of this research.

The Bivariate GARCH model is applied to the data from the 74 companies ever listed in LQ45 Index ranging from year February 2006 to January 2016. They are divided volume size group for three different indexes. The results show that the three indexes show one-way causality between return and trading volume. It is found that return Granger-Cause trading volume. On the other hand, it is only found in low volume size index that return volatility Granger-Cause trading volume. Then the result can be concluded that hypothesis one is rejected group, meanwhile hypothesis two is accepted, where there is one-way causal relationship that return granger-cause trading volume. As investors stock return can be used for predict the future volume but reverse relationship is not useful in Indonesia Stock Market (IDX).

Further relationship of return and trading volume is explained in the leverage and anti-leverage effects. All of the indexes from volume size group indicate a positive time-lag correlation between return and trading volume. It can be concluded for further relationship for return and trading volume for volume size group that return and trading volume has anti-leverage effects since shows more than ten days positive time lag correlation so hypothesis three is accepted. It means there are synchronous movements between return and trading volume in IDX. In other word, stock return and trading volume has positive correlation, when the price goes up this will induce a high trading volume, while a low trading volume is induced when the price goes down. As a investors this leverage and anti-leverage relation can be used one of the factors in their active investment strategy.

The results from the researches in developed markets are not applicable to Indonesian's markets which are a developing market. Since in developed markets, many results indicate a bidirectional relationship between return and trading volume. Whereas, the result in many developing markets, including this research, only indicates one-way causal relationship, where return granger-cause trading volume. It is suspected that the difference between the results from both the developed and developing markets is caused by the different market characteristic of each market.

\section{REFERENCES}

Aggarwal, S., \& Verma, H. L., 2014, Investors 'Perceptions on Trading Volume and Stock Return Volatility in Indian Stock Market. Journal of Applied Economics, XIII(4), 52-73.

Al-jafari, M. K., Salameh, R. M., \& Habbash, M. R., 2011, Investigating the Relationship between Stock Market Returns and Macroeconomic Variables : Evidence from Developed and Emerging Markets. International Journal of Finance and Economics, 79(79), 6-30.

Ananzeh, I. E. N., \& Al-jayousi, A. M., 2013, Relationship Between Market Volatility and Trading Volume: Evidence from Amman Stock Exchange International Journal of Business and Social Science, 4(16), 188-198. 
Ane, T., \& Ureche-rangau, L., 2008, Does trading volume really explain stock returns volatility? Journal of International Financial Markets, Insitution and Money, 18(3), 216-235.

Assan, A., \& Thomas, S., 2013, Stock returns and trading volume: does the size matter? Investment Management and Financial Innovations, 10(3).

Bohl, M. T., \& Henke, H., 2003, Trading volume and stock market volatility: The Polish case. International Review of Financial Analysis, 12(5), 513-515.

Bremer M, Hiraki T., 1999, Volume and individual security returns on the Tokyo Stock Exchange. Pacific Basin Financial Journal 7:351-370

Campbell, J. Y., Grossman, S. J., \& Jiang, W., 1993, Trading Volume and Serial Correlation in Stock Returns. The Quarterly Journal of Economics.

Chen, G., Qiu, T., Jiang, X., Zhong, L., \& $\mathrm{Wu}, \mathrm{X} ., 2015$, How trading volume responds to return in financial dynamics? Physica A, 424, 73-81.

Chen, S., 2012, Revisiting the empirical linkages between stock returns and trading volume. Journal of Banking and Finance, 36(6), 1781-1788.

Chen, G. -M, M. Firth, O. M. R., 2001, The Dynamic Relation Between Stock Returns , Trading Volume, and Volatility. The Financial Review, 38(Februari 2001), 153-174.

Chuang, W., Liu, H., \& Susmel, R., 2012, The bivariate GARCH approach to investigating the relation between stock returns, trading volume, and return volatility. Global Finance Journal, 23(151), 1-15.
Ciner, C., 2015, Time variation in systematic risk, returns and trading volume: Evidence from precious metals mining stocks. International Review of Financial Analysis, 41, 277-283.

Darrat A F, Rahman S and Zhong M., 2003, "Intraday Trading Volume and ReturnVolatility of the DJIA Stocks: A Note", Journal of Banking and Finance, Vol. 27,pp. 2035-2043.

Granger, C.W., O. Morgenstern, 1963. Spectral Analysis of New York Stock Market Prices, Internatinal Review of Social Sciences, 16, 1-27.

Fama, F., \& French, R., 1993, Common risk factors in the returns stocks and bonds *. Journal of Financial Economics, 33, 3-56.

Gebka, B., \& Wohar, M. E., 2013, Causality between trading volume and returns: Evidence from quantile regressions. International Review of Economics and Finance, 27, 144-159.

Ghysels, É., Gouriéroux, C., \& Jasiak, J., 2000, Causality between Returns and Traded Volumes. Journal Annals of Economics and Statistics, (60), 189206.

Hill, R. C., Griffiths, W. E., \& Lim, G. C., 2010, Principle of Econometrics (4th ed.). United State of America: Wiley.

Karpoff, J. M., 1987, The Relation Between Price Changes and Trading Volume: A Survey. Journal of Financial and Quantitative Analysis, 22(1), 109-126.

Lee, B.-S. and O. M. Rui, 2002, 'The dynamic relationship between stock returns andtrading volume: domestic and cross-country evidence', Journal of Banking and Finance26, 51-78. 
Length, F., 2007, An empirical study of the relation between stock return volatility and trading volume in the BRVM. African Journal of Business Management, 1(October), 176-184.

Llorente, G., Michael, R., Saar, G., \& Wang, J., 2002, Dynamic Volume-Return Relation of Individual Stocks Guillermo Llorente; Roni Michaely; Gideon Saar; Jiang Wang. Review Literature And Arts Of The Americas, 15(4), 1005-1047.

McKenzie, M.D., Faff, R.W., 2003, The determinants of conditional autocorrelation in stock returns. Journal of Financial Researches. 26, 259-274

Mubarik, F., \& Javid, A. Y., 2009, Relationship Between Stock Return, Trading Volume and Volatility:Evidence From Pakistani Stock Market. Asia Pacific Journal of Finance and Banking Research, 3(3), $1-17$.

Mulherin, H., Foundation, N. S., \& Long, D., 1993, Trading Volume and Serial Correlation In Stock Returns. The Quarterly Journal of Economics, 108(4), 905-939.

Otavio, A., Medeiros, R. De, Ferdinandus, B., \& Doornik, N. Van., 2006, The Empirical Relationship between Stock Returns, Return Volatility and Trading Volume in the Brazilian Stock Market. EnANPAD 2006, 5(1), 1-15.
Pathirawasam, C., 2011, The Relationship Between Trading Volume and Stock Returns. Journal of Competitiveness, 41, 41-50.

Pisedtasalasai, A., \& Gunasekarage, A., 2007, Causal and Dynamic Relationships among Stock Returns, Return Volatility and Trading Volume: Evidence from Emerging markets in South-East Asia. Asia Pacific Financial Markets, 14(4), 277-297.

Queirós, S. M. D., 2016, Trading volume in financial markets: An introductory review. Chaos, Solitons and Fractals, 88, 24-37.

Sapna, \& Dani, D. V., 2014, Stock Market and Factors Affecting Trading Volume. International Journal of Advance Research in Computer Science and Management Studires, 2, 47-53.

Shen, J., \& Zheng, B., 2009, On returnvolatility correlation in financial dynamics. EPL (Europhysics Letters), 88(2), 28003.

Wang, J.,1994, A Model of Competitive Stock Trading Volume. Journal of Political Economy, 102(1), 127.

Yadav, M., Aggarwal, S., \& Khurana, S., 2015, The Volume-Returns Relationship in the Indian Stock Market. Journal of Financial Risk Management, 12(4), 35-48. 